\title{
Household water treatment and safe storage - effectiveness and economics
}

\author{
Stefanie M. L. Stubbé ${ }^{1}$, Alida Pelgrim-Adams ${ }^{2}$, Gabor L. Szántó ${ }^{2}$, and Doris van Halem ${ }^{1}$ \\ ${ }^{1}$ TU Delft, Civil Engineering, Sanitary Department Stevinweg 1 (Building 23), \\ $2628 \mathrm{CN}$ Delft, the Netherlands \\ ${ }^{2}$ PRACTICA Foundation, Geulwg 16, 3356 LB, Papendrecht, the Netherlands \\ Correspondence to: Stefanie Stubbé (s.m.l.stubbe@student.tudelft.nl)
}

Received: 1 May 2015 - Published in Drink. Water Eng. Sci. Discuss.: 17 August 2015

Accepted: 23 March 2016 - Published: 14 April 2016

\begin{abstract}
Household Water Treatment and safe Storage (HWTS) systems aim to provide safe drinking water in an affordable manner to users where safe piped water supply is either not feasible or not reliable. In this study the effectiveness, economic parameters and costs of three selected HWTS systems were identified. The selected systems are SODIS, ceramic filter and biosand filter. These options were selected based on their accessibility, affordability and available scientific data. Data was obtained through peer-reviewed literature, reports, webpages and informal sources. The findings show a wide dispersion for log removal of effectiveness of the HWTS systems. For bacteria (E. coli), log removals of 1-9 (SODIS), 0.5-7.2 (ceramic) and 0-3 (biosand) were reported. In the case of viruses (mostly echovirus and bacteriophages), log removals of 0-4.3 (SODIS), 0.09-2.4 (ceramic) and $0-7$ (biosand) were found. The dispersions of log removals for both bacteria and viruses range from nonprotective to highly protective according to WHO performance targets. The reported costs of HWTS systems show a wide range as well. The price per cubic meter water is found to be EUR 0-8 (SODIS), EUR 0.37-6.4 (ceramic) and EUR 0.08-12.3 (biosand). The retail prices found are: negligible (SODIS), USD 1.9-30 (ceramic) and USD 7-100 (biosand). No relationship was observed between removal efficiency and economics of the three systems.
\end{abstract}

\section{Introduction}

In many parts of the world, people do not have access to safe drinking water, this is especially true in rural areas of developing countries (Unicef et al., 2012). Conventional piped water delivery and similar centralized systems are not feasible for rural and peri-urban communities in the near future, implying that they are left with the responsibility (and need) to collect, treat and store their own water (Brown Sobsey and Loomis, 2008). Where groundwater is inaccessible or contaminated, these users depend on household water treatment (HWTS) systems for safe drinking water (Sobsey et al., 2008). These HWTS systems have the goal to provide safe drinking water in an affordable and sustainable manner (Duke et al., 2006) while being simple and easy to manage by their users (Heinsbroek and Peters, 2014). As such, these systems are crucial in reducing occurrence of diarrheal and other debilitating illnesses (Meierhofer and Landolt, 2009; Stauber et al., 2009). Efficiency in providing safe water differs per method. To indicate removal efficiency, the WHO produced guidelines (WHO, 2004) to define default performance targets to indicate a certain removal efficiency for different pathogens as "interim", "protective" or "highly protective" (see Fig. 1).

When looking at the economics of HWTS systems, it is common practise to look at the price per produced $\mathrm{m}^{3}$ water (NWP, 2010). Generally, this is calculated by dividing the investment and operational costs over the produced water during the lifetime of the technology (NWP, 2010).

Price $\left[\right.$ Euro $\left.^{-3}\right]=\frac{\text { Investment }+ \text { operational costs }}{\text { Produced water }}$

The objective of this paper is to give an overview of the potential effectiveness according to the WHO performance tar- 


\begin{tabular}{|c|c|c|c|}
\hline Target & $\begin{array}{l}\log _{10} \\
\text { reduction } \\
\text { required: } \\
\text { Bacteria }\end{array}$ & $\begin{array}{l}\log _{10} \\
\text { reduction } \\
\text { required: } \\
\text { Viruses }\end{array}$ & $\begin{array}{l}\log _{10} \\
\text { reduction } \\
\text { required: } \\
\text { Protozoa }\end{array}$ \\
\hline $\begin{array}{l}\text { Highly } \\
\text { protective }\end{array}$ & $\geq 4$ & $\geq 5$ & $\geq 4$ \\
\hline Protective & $\geq 2$ & $\geq 3$ & $\geq \mathbf{2}$ \\
\hline Interim * & \multicolumn{3}{|c|}{$\begin{array}{c}\text { Achieves "protective" target for two classes of } \\
\text { pathogens and results in health gains }\end{array}$} \\
\hline \multicolumn{4}{|c|}{$\begin{array}{l}\text { Summary of performance requirements for small-scale and household } \\
\text { drinking-water treatment, based on reference pathogens Campylobacter } \\
\text { jejuni, Cryptosporidium and rotavirus (see Appendix 1). }\end{array}$} \\
\hline
\end{tabular}

Figure 1. WHO guidelines on default performance targets of HWTS systems (WHO, 2004).

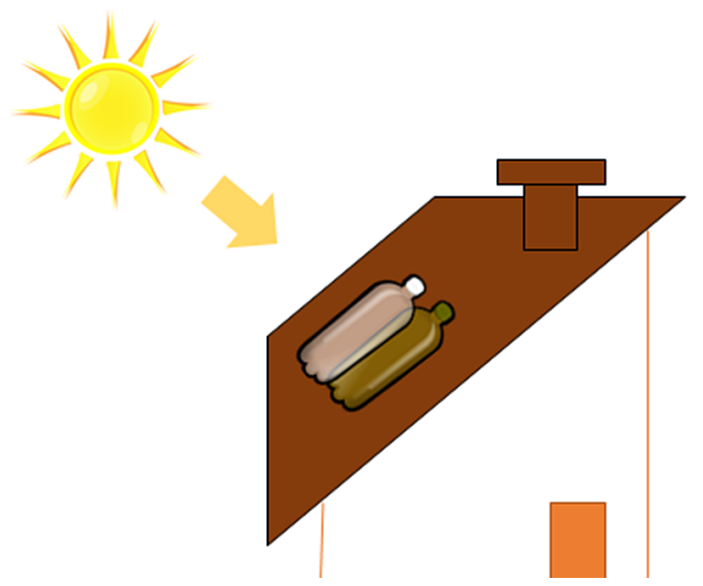

Figure 2. Schematic illustration of SODIS.

gets and the costs paid by the user of three HWTS systems: SODIS, ceramic filters and biosand filters. These three systems offer the most optimal combination of (i) accessibility and affordability even for the poorest, (ii) most widespread in use in low-income settlements and (iii) a considerable body of literature exists for these three systems.

\subsection{SODIS}

SODIS is based on the principle of disinfection by solar radiation (see Fig. 2). The procedure is straightforward; an unscratched and uncoloured PET or glass bottle is filled with water and exposed to direct sunlight for a minimum of $6 \mathrm{~h}$ (Heinsbroek and Peters, 2014). Water with low oxygen and high turbidity levels has to be pre-treated (Acra et al., 1990; Meierhofer and Landolt, 2009).

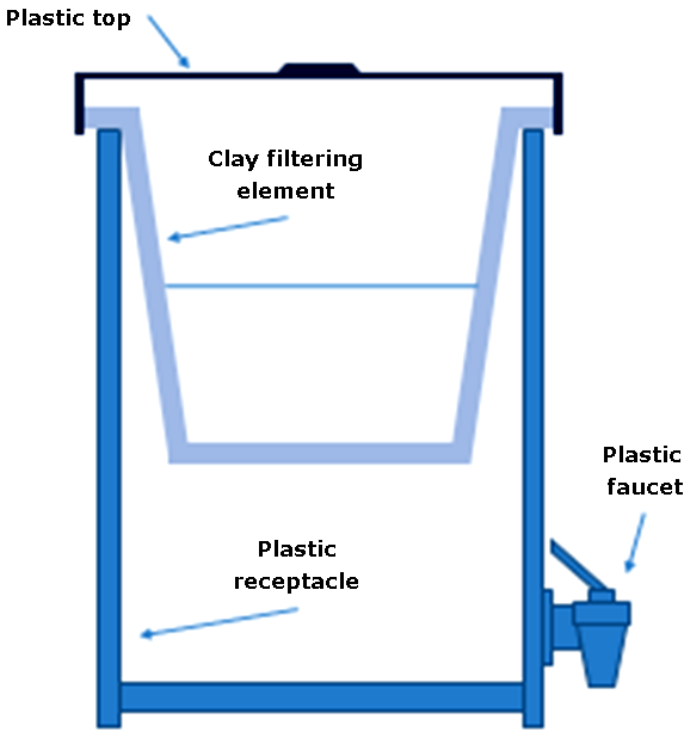

Figure 3. Schematic illustration of ceramic Pot filter (Van Halem et al., 2007).

\subsubsection{Ceramic filters}

The ceramic filter is based on the following principle: a porous media of fired clay that retains microbes by size exclusion and high tortuous properties (it traps microbes in the sharp bends; Hunter, 2009; Sobsey et al., 2008; van der Laan et al., 2014). Many variations of ceramic filters exist; e.g. pot filters or "water purifier" (see Fig. 3; Akvopedia, 2014b; Potters for Peace, 2014a), candle filters (Sobsey et al., 2008) and Tulip siphon filter (Basic Water Needs, 2014; Tulipfilter, 2013). Periodic scrubbing and rinsing is necessary to remove impurities (Sobsey et al., 2008).

\subsection{Biosand filter}

Biosand filters consist of a concrete or plastic frame filled with crushed rock (sand) filter media of $0.15-0.35 \mathrm{~mm}$ particle (Murphy et al., 2010b; see Fig. 4). Two filter mechanisms govern the removal principle of biosand filters: physical removal of organic matter and turbidity (Sobsey et al., 2008) and biological removal of colloidal particles and harmful pathogens in the so-called Schmutzdeke (Duke et al., 2006; Hunter, 2009; Weber-Shirk and Dick, 1997). The filter can be cleaned manually by removing the top few centimetres of sand and disposing the overlying water (Sobsey et al., 2008).

\section{Effectiveness}

In this section an in-depth description is given of the removal mechanisms of each of the selected HWTS systems and the corresponding removal efficiency. Both lab and field studies are used to give an overview of the reported effectiveness. 


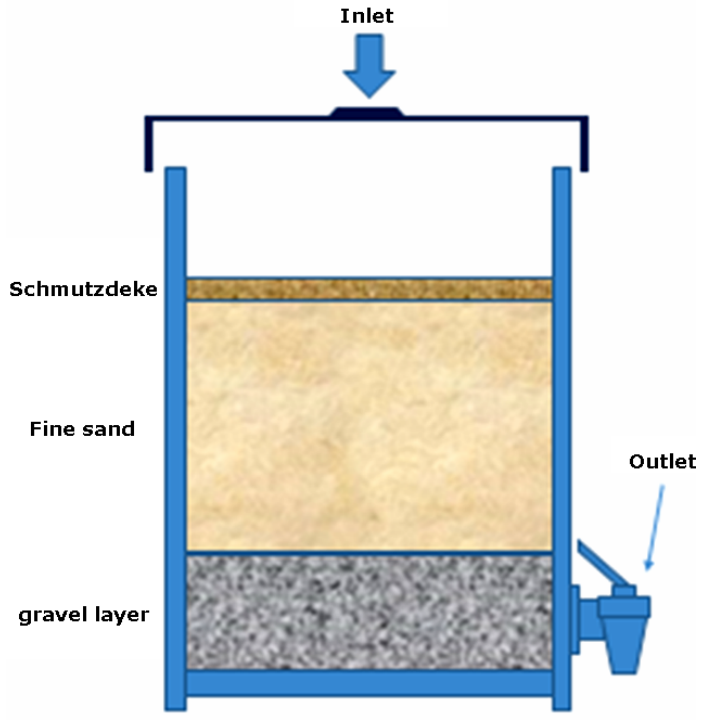

Figure 4. Schematic illustration of biosand filter (not on scale).

Insufficient data was found on the log removal of protozoa, so this pathogen is excluded from this study.

\subsection{SODIS}

The inactivation mechanisms of the solar radiation is based on direct UVB absorption (damaging the pathogenic DNA), optical inactivation (via reactive oxygen species) and thermal inactivation (denaturation; Reed, 2004). A synergy between optical inactivation and thermal inactivation was signalled at temperatures between $40-50^{\circ} \mathrm{C}$ (Reed, 2004; Wegelin et al., 1994). Several parameters were suggested to enhance the SODIS treatment: black background surface (to reflect sunlight; Martín-Domínguez et al., 2005; Wegelin and Sommer, 1998), unscratched container material (diminish scattering; Wegelin and De Stoop, 1999), added photosensitizers (increase production of oxygen reactive species; Chilvers et al., 1999) and glass bottles (Duffy et al., 2004). Critics are focused on the potential leaching of plasticizers into the treated water (Reed, 2004). However, Wegelin et al. (2001) has shown that this is only the case at the outer surface of the bottles and not in the treated water.

In Figs. 5 and 6, a summary is given of the found removal efficiencies of SODIS for bacteria $(E$. coli) and viruses (mostly echovirus and bacteriophage) respectively. The majority of the research conditions lies between $40-65^{\circ} \mathrm{C}$ and 4-6h. For bacteria and viruses the $\log$ removal was between 1-9 and 0-4.3 respectively (Acra et al., 1990; Akvopedia, 2013; Dejung et al., 2007; Fujioka and Yoneyama, 2002; Heaselgrave et al., 2006; Joyce et al., 1996; Lonnen et al., 2005; Martín-Domínguez et al., 2005; McGuigan et al., 2012; Meyer and Reed, 2004; Sodis.ch, 2011). The majority of the results are centred around 2.5-5 log removal for bacteria and 1-4 log removal for viruses respectively.

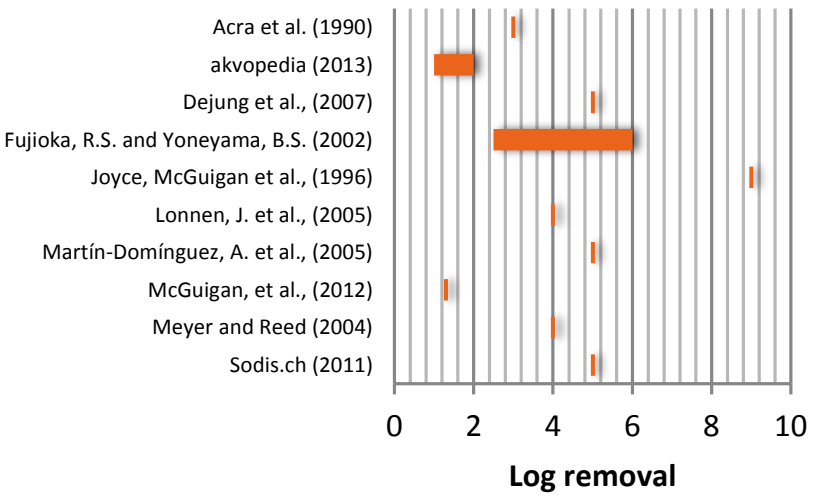

Figure 5. Log removal of SODIS for bacteria.

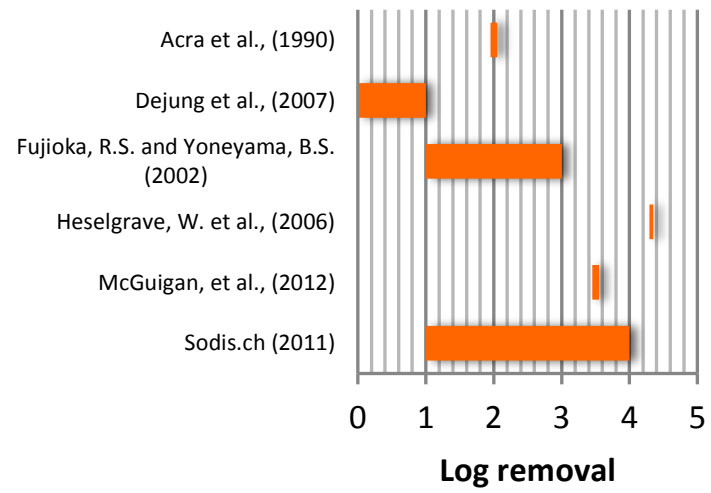

Figure 6. Log removal of SODIS for viruses.

\subsection{Ceramic filters}

By means of meta-regression, Hunter (2009) concluded that compared to other interventions (chlorine, SODIS, biosand filter and combined coagulant-chlorine), the ceramic filter shows the highest effectiveness on the long term. Most filters are manufactured by adding colloidal silver to increase efficiency. Silver inactivates bacteria and other pathogens through three mechanisms: reaction with thiol (in structural groups and functional proteins), structural changes in cell membrane and reaction with nucleic acids (Russell et al., 1994). There are different ways to impregnate silver in the filter: dipping, painting, pulse injections and fire-in (Oyanedel-Craver and Smith, 2007; Ren and Smith, 2013). Van der Laan et al. (2014) and Oyanedel-Craver and Smith (2007) did not find a significant difference in removal efficiency for different silver application methods. On the contrary, the storage time in the receptacle of a silverimpregnated filter was found to be an important parameter in the bacterial removal efficiency; lengthy contact time in the receptacle led to higher removal efficiencies (van der Laan et al., 2014). Neither does an addition of iron appear to increase the removal efficiency in their research (Brown et al., 2008). Concerns exist about the virus removal of ceramic fil- 


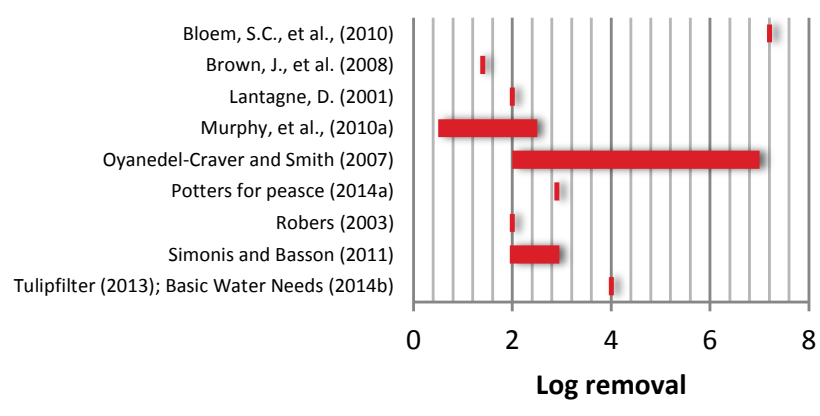

Figure 7. Log removal of ceramic filters for bacteria.

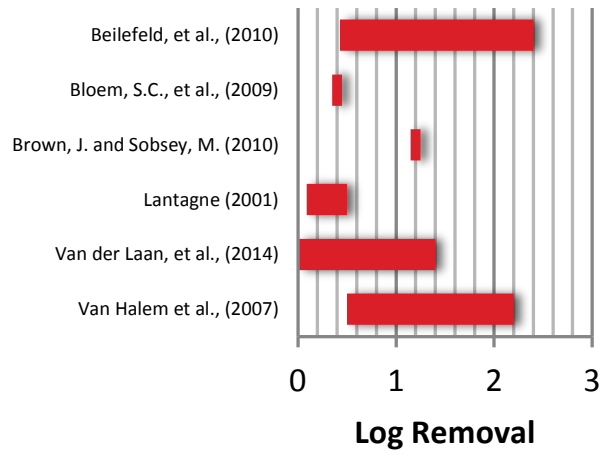

Figure 8. Log removal of ceramic filters for viruses.

ters, since reported removal efficiencies do not reach WHO guidelines (Murphy et al., 2010a; van der Laan et al., 2014), and show high distribution (Bielefeldt et al., 2010). No critical parameter was yet identified to improve the virus removal efficiency (van der Laan et al., 2014).

In Figs. 7 and 8, a summary is given of the found removal efficiencies of ceramic filters for bacteria (E. coli) and viruses (mostly echovirus and bacteriophage) respectively. The log removal of ceramic filters for bacteria and viruses were between 0.5-7 and 0.09-2.4 respectively (Basic Water Needs, 2014; Bielefeldt et al., 2010; Bloem et al., 2009; Brown et al., 2008; Brown and Sobsey, 2010; Lantagne, 2001; Murphy et al., 2010a; Oyanedel-Craver and Smith, 2007; Potters for Peace, 2014; Roberts, 2003; Simonis and Basson, 2011; Tulipfilter, 2013; van der Laan et al., 2014; Van Halem et al., 2007). For removal of bacteria, most information sources report log removals between 1.3 and 4 . The log removals of viruses are considerably lower with most information sources reporting log removals between 0.4 and 1.4.

\subsection{Biosand filters}

The removal mechanism of the biosand filter is based on the slow sand filtration principle and depends on the daily volume loaded to the filter (Elliott et al., 2008). The optimal volume is investigated to be equal to or smaller than the pore volume (Elliott et al., 2011). When larger charge volumes are exposed to the filter, a decrease in removal efficiency is found

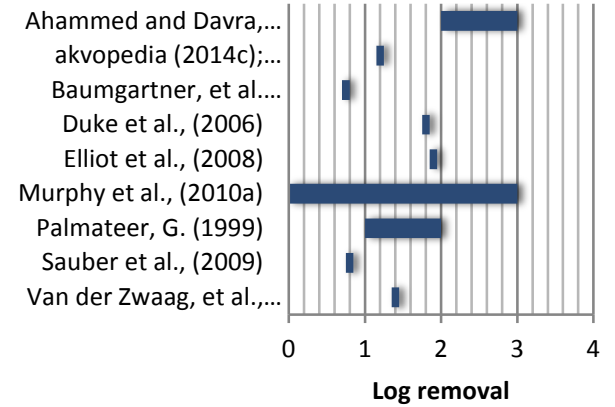

Figure 9. Log removal of biosand filters for bacteria.

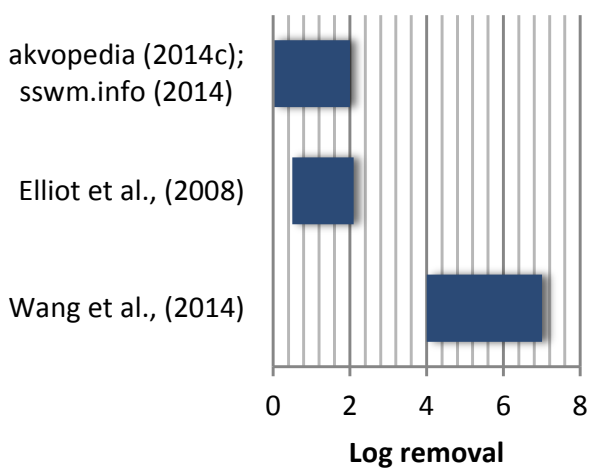

Figure 10. Log removal of biosand filters for viruses.

(Baumgartner et al., 2007). Although this HWTS system is designed for intermitted use, continuous use of the biosand filter has higher removal efficiencies (Young-Rojanschi and Madramootoo, 2014). Introduction of iron oxide in the sand layer shows improved levels of pathogen removal and is especially beneficial after cleaning or in the ripening period (Ahammed and Davra, 2011). It is suggested that the Schmutzdeke contributes to the virus attenuation by the production of microbial exo-products (proteolytic enzymes) or grazing bacteria on viruses (Elliott et al., 2011; Huisman et al., 1974). Concerns exist about the lack of guidelines for the post-treatment of the removed Schmutzdeke during maintenance since this contains opportunistic pathogens and therefore poses an health risk to consumers (Hwang et al., 2014).

Figures 9 and 10 provide a summary of the reported removal efficiencies of biosand filters. Overall, the reported log removals of biosand filters for bacteria $(E$. coli) and viruses (mostly echovirus and bacteriophage) are between 0-3 and 0-7, respectively (Ahammed and Davra, 2011; Akvopedia, 2014c; Baumgartner et al., 2007; Duke et al., 2006; Elliott et al., 2008; Murphy et al., 2010a; Palmateer, 1999; Sswm.info, 2014; Stauber et al., 2009; Vanderzwaag et al., 2009; Wang et al., 2014). The log removal of bacteria is centred on 0.4-2; while the distribution of log removals reported for viruses is widely scattered. 


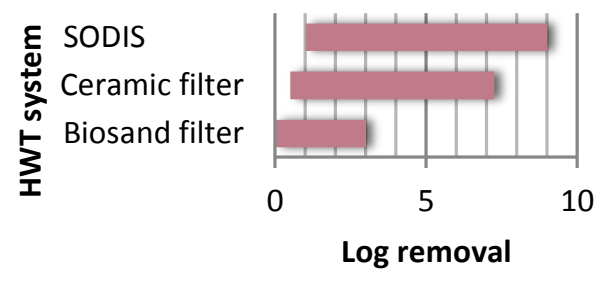

Figure 11. Overview of the overall range of found log removals in Sects. 2.1-2.3 for bacteria.

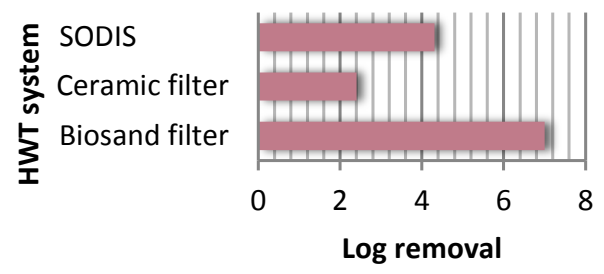

Figure 12. Overview of the overall range of found log removals in Sects. 2.1-2.3 for viruses.

\subsection{Overview of effectiveness}

Figures 5-10 show that the removal efficiency of HWTS systems differs per pathogen type and per study. The removal efficiencies found in the reviewed articles, are not always compatible with the target performance of the WHO (see Fig. 1), which corresponds with the results of previous studies such as Murphy et al. (2010a) and van der Laan et al. (2014). The difference between highest and lowest reported efficiencies of each HWTS system is what makes the difference between safe or unsafe water produced with this particular HWTS system. Hence, the question arises whether certain removal efficiency can be guaranteed for the HWTS systems.

In Figs. 11 and 12, the total range of lowest to highest reported log removal reported is shown per HWTS system. It can be seen that SODIS have the highest reported efficiency for bacteria removal ( $9 \log$ removal) whereas, biosand filter report the highest reported efficiency for virus removal (7 log removal). Biosand filters show the lowest (zero) removal efficiency for bacteria whereas for virus removal, all HWTS systems have been reported with a zero log removal in one or more studies.

In the past, numerous studies questioned the effectiveness of HWTS systems. Various field test results indicated that HWTS systems may not always improve and sometimes even worsen the pathogenic state of the water (Murphy et al., 2010a). The lack of blinding and considerable heterogeneity in the results of HWTS systems show signs of concerns (Hunter, 2009). Moreover, it is reported that the research method can have a big impact on the reported efficiency (van der Laan et al., 2014). The reported removal efficiency also depends on the indicator pathogen used, as shown by Palmateer (1999) and Elliott et al. (2008). Quality tests are not yet globally standardized (Rayner et al., 2013), so that a fair comparison between data sets is challenging.

\subsection{Human factors}

Operating conditions can also reduce the effectiveness of HWTS systems (Baumgartner et al., 2007). The effectiveness of HWTS systems does not only depend on technology, but also on human factors. When the HWTS system is not operated properly, exposure to pathogens can remain high. For example, it is common that people use the storage container of the device to collect dirty untreated water to feed the HWTS system, reducing the effectiveness of the device (Murphy et al., 2010a). Other reasons why in practice the effectiveness of HWTS systems is reduced: (i) only part of the used water is treated (Sobsey et al., 2008), as the water production of HWTS systems can be reduced in time due to clogging (ii) replacement-purchases are unfeasible (Brown et al., 2009; Hunter, 2009; Meierhofer and Landolt, 2009), (iii) the water is only intermittently treated (Sobsey et al., 2008), (iv) limited guidance to determine whether pre-treatment is necessary (Sobsey et al., 2008), (v) usage of the device simply stopped (Hunter, 2009), or (vi) selling it to a friend or relative (Brown et al., 2009). For ceramic filters, the rate of participation reduction is estimated at $2 \%$ per month (Brown et al., 2009). The found diversity in effectiveness prompts that sufficient training and continued monitoring is needed to increase and sustain proper HWTS device management. Preferably, this could be done by a well-embedded local agent in order to increase acceptability (Meierhofer, 2006). Understanding the human factors that influence the real effectiveness of the HWTS systems is crucial for widespread adoption and sustained usage (Sobsey et al., 2008).

\section{Economical evaluation}

In this section, the parameters that determine the purchase price of a HWTS system (see Fig. 12) and the reported prices for the three selected HWTS systems are discussed (see Table 1).

\subsection{Economic Parameters}

The price of HWTS systems depends strongly on project area (Potters for Peace, 2014b; H. Jansen, personal communication, 2014). This can be explained by the fact that the price of HWTS systems is determined by (at least) four parameters (see Fig. 12). The first cost-parameter for HWTS systems is the production costs (or investment costs) including, materials (plastic, sand, ceramic), labour and basic tools (Basic Water Needs, 2014; Potters for Peace, 2014). These costs depend on the type of HWTS system and the region of production. Factories in China and India are frequently used, due to lower labour costs. The second parameter is distribution (Stuurman 
Table 1. Overview of the price and retail price of HWTS systems.

\begin{tabular}{|c|c|c|c|c|c|}
\hline Technology & Adjustment & $\begin{array}{l}\text { Total Water } \\
\text { Production } \\
\left(\mathrm{m}^{3} \text { unit }^{-1}\right)^{\mathrm{b}}\end{array}$ & $\begin{array}{l}\text { Price } \\
\left(\text { USUSD m }^{-3}\right)^{\mathrm{a}}\end{array}$ & $\begin{array}{l}\text { Retail Price } \\
\left(^{(U S U S D)^{a}}\right. \\
\text { (without subsidies) }^{\mathrm{a}}\end{array}$ & Reference \\
\hline SODIS & - & $\begin{array}{l}0.243 \\
0.292\end{array}$ & $\begin{array}{l}0.53-2.03 \text { new } \\
0-0.27 \text { used } \\
3-8\end{array}$ & $\begin{array}{l}0 \\
0\end{array}$ & $\begin{array}{l}\text { NWP (2010) } \\
\text { NWP (2010) } \\
\text { Akvopedia (2013) } \\
\text { CAWST (2012) }\end{array}$ \\
\hline Ceramic & $\begin{array}{l}\text { Water4life } \\
\text { Candle Filter } \\
\text { Potters for Peace }\end{array}$ & 7 & $\begin{array}{l}0.4-0.44 \\
1.14-5.2 \\
2-5 \\
1\end{array}$ & $\begin{array}{l}5-15 \\
8-10 \\
5.69-7.32 \\
26.02 \\
\\
9.76-17.89 \\
7.5 \\
5.4-28 \\
1.87-20.33 \\
15-30 \\
15-25 \\
12\end{array}$ & $\begin{array}{l}\text { NWP (2010) } \\
\text { Oyanedel-Craver and Smith (2007) } \\
\text { Brown et al. (2009); Sobsey et al. (2008) } \\
\text { NWP (2010) } \\
\text { Tulipfilter (2013) } \\
\text { Basic Water Needs (2014) } \\
\text { Akvopedia (2014b) } \\
\text { CAWST (2012) } \\
\text { Roberts (2003) } \\
\text { NWP (2010) } \\
\text { Akvopedia (2014a) } \\
\text { NWP (2010) } \\
\text { CAWST (2012) } \\
\text { CAWST (2012); Potters for Peace (2014c) } \\
\text { S. Chan (personal communication, 2014) }\end{array}$ \\
\hline Biosand & $\begin{array}{l}\text { Plastic } \\
\text { Iron oxide filter }\end{array}$ & $\begin{array}{l}262.8-788.4 \\
87.6-262.8\end{array}$ & $\begin{array}{l}0.07-0.15 \\
10\end{array}$ & $\begin{array}{l}6.99-22.76 \\
12-40 \\
25-100 \\
7-28 \\
12-30 \\
75 \\
15-36\end{array}$ & $\begin{array}{l}\text { NWP (2010) } \\
\text { Akvopedia (2014c); Sswm.info (2014) } \\
\text { Sobsey et al. (2008) } \\
\text { Ahammed and Davra (2011) } \\
\text { CAWST (2012) } \\
\text { CAWST (2012) } \\
\text { Ahammed and Davra (2011) }\end{array}$ \\
\hline
\end{tabular}

${ }^{\mathrm{a}}$ Conversion used where necessary 1.23 EUR/USD (Bloomberg, 2014). ${ }^{\mathrm{b}}$ Conversion used where necessary; daily production $\left(\mathrm{m}^{3}\right) \times 365\left(\right.$ days yr $\left.{ }^{-1}\right) \times$ unit life-time. $^{2}$

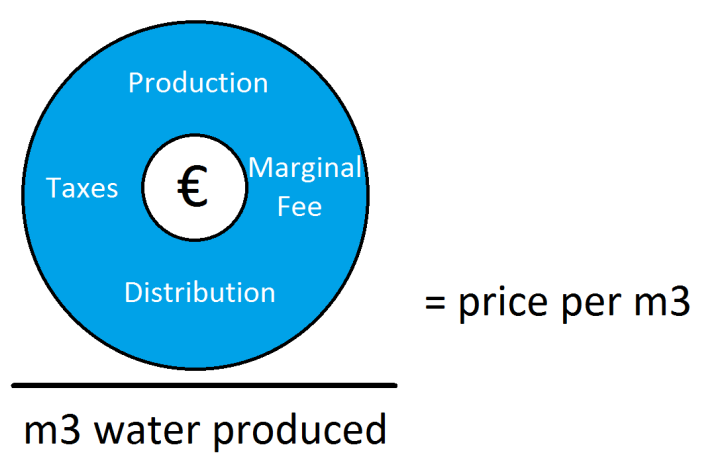

Figure 13. Economic Parameters that determine the costs of HWTS systems.

et al., 2010). Transport costs between production and project area depend on quantity and weight. In-land and over-sea transportation can differ considerably in total cost. For example, getting new ceramic filters to Ethiopia from India is more economic over-sea than over land (Basic Water Needs, 2014). This parameter is estimated to be the most dominant (Basic Water Needs, 2014). However, high variability in both manufacturing and transportation costs translate into a severe limitation in data regarding the relation between costs in logistics and retail price. Local production factories are established to diminish distribution costs and enhance local economy (Brown, 2007). The third parameter is taxes. Depending on the country, HWTS systems need to be imported and import fees are involved. A possible fourth parameter is the (local) distributor's fee that is required to maintain his business. A retailer (of spare parts) of HWTS systems in Ethiopia, for example, can only remain in business if earnings are sufficiently attractive (Basic Water Needs, 2014). Depending on the developed supply chain, a (local) distributor will organize or co-organize distribution and sales in the project area.

\subsection{Costs of HWTS systems}

Only a limited number of peer-reviewed articles mention costs of HWTS systems, and in general only retail prices were mentioned. Retail price depends on the four parameters mentioned in the previous section and is the price eventually paid by the user. The retail price could be converted to the price per $\mathrm{m}^{3}$, when the potential volume of water that can be treated with one filter is known (see Fig. 13). This potential 


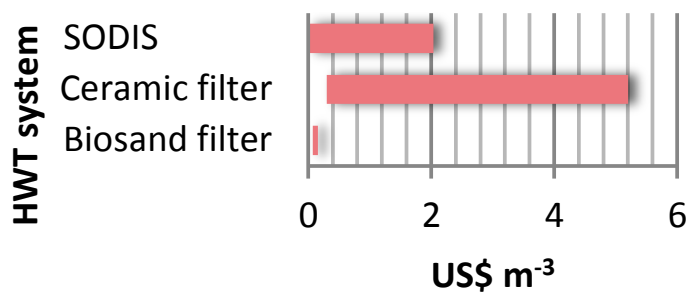

Figure 14. Price ranges (USD m ${ }^{-3}$ ) for the three selected HWTS systems (outlier of biosand filter is neglected).

volume is dependent on the lifetime of the filter, the flowrate, the sustainability of the system, etc. Reliable and sufficient information about this total potential volume is often lacking, therefore the retail price is mentioned separately from the price per $\mathrm{m}^{3}$ water produced (see Table 1). Also, subsidies are not included in the calculations as it would be an unfair comparison with unsubsidized HWTS systems. However, it is noted that subsidies compromise a realistic and omnipresent part of emerging water sectors in developing countries. In practically emerging water sectors, subsidies play a crucial and - at present - decisive role for NGOs to arrange donor projects where consumers pay a reduced and affordable price for water treatment devices (Stuurman et al., 2010).

In Table 1, a summary is given of the price per $\mathrm{m}^{3}$ and retail price per HWTS system. SODIS has a retail price of USD 0, since old PET bottles can be used. When new bottles are used, only a small investment is necessary (NWP, 2010). The costs per $\mathrm{m}^{3}$ are related with the retail price. The outlier of USD 3-8 $\mathrm{m}^{-3}$ by Akvopedia (2013) is assumed to be an error, since it does not correspond with the numbers in the rest of the text of the same reference. For ceramic filters, the range of retail prices is between USD 1.9-30, with most of the references mentioning prices of around USD 15. The differences in price can be explained by the parameters elaborated in the previous section. The price per $\mathrm{m}^{3}$ ranges between USD 0.3 and USD 5.2, which depends on the estimation of the potential amount of water that can be treated with the filter. For biosand filters, large ranges are found in the price per $\mathrm{m}^{3}$ and retail price: $0.06-8.13$ and USD 7-100 respectively (conversion 1.23EUR/USD used where necessary following; Bloomberg, 2014). The outlier in price per $\mathrm{m}^{3}$ of USD 10 is unreliable, since no argumentation is given in the reference (Akvopedia, 2014c). The outlier in retail price of USD 100 for concrete is also stated without further explanation, (Sobsey et al., 2008).

Overall, it is found that the biosand filter has the lowest price per $\mathrm{m}^{3}$ produced what can be explained by its long life time, low maintenance costs and sustainable flowrate. Biosand filters do have the highest retail price (even when the highest outlier is neglected). Although SODIS is also a cheap technology, it requires a (small) investment when new (glass) bottles are used and it only produces little amount of

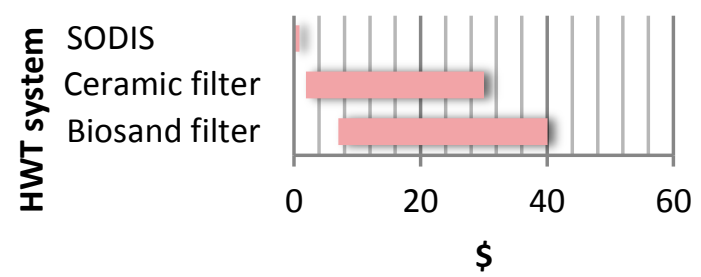

Figure 15. Ranges for the retail price of the three selected HWTS systems (outlier of SODIS is neglected).

water per bottle. SODIS does have the cheapest retail price. It is shown that ceramic filters have the biggest range of price per $\mathrm{m}^{3}$ water with the highest numbers. Ceramic filters are prone to breakage and the flowrate can decrease over time due to clogging. By far most independent research exists on ceramic filters compared to the other HWTS systems. In Figs. 14 and 15, an overview of the price ranges is given, neglecting the outliers mentioned above.

\subsection{Constraints to economic evaluation}

Most cost estimations of HWTS systems are found on websites of coordinating NGOs or device suppliers. Because the information is practice-oriented, the reliability of this information is likely to be fluctuating. More direct information from local producers turned out to be necessary. For example, Resource Development International in Cambodia reveals a standing quotation of a ceramic filter for USD 12 (RDI, 2014), which is in line with the prices in other sources. Since the price of HWTS systems does not only depend on the four parameters mentioned before, but is also fluctuating in time and susceptible to exchange rates. The price of the HWTS system today is therefore different from the price indicated for 2007 (PRACTICA Foundation, 2014). This study does not include these changes. The prices mentioned in table 1 are considered to be valid for the year of the respective reference.

\section{Conclusions}

In this study the removal efficiencies and economics of three selected Household Water Treatment and safe Storage (HWTS) systems were compared: SODIS, ceramic filters and biosand filters. Overall, no direct relationship between HWTS system's removal efficiency and economics was observed. This article aimed to be a guide through the currently available HWTS, however, it may be concluded that insufficient reliable information is available for a straightforward recommendation for the most effective and affordable HWTS.

For SODIS, low retail prices and intermediate prices per $\mathrm{m}^{3}$ were observed with a range of removal efficiencies for bacteria (E. coli) from "non-protective" to "highly protec- 
tive" and for viruses (mostly echovirus and bacteriophages) from "non-protective" to "protective" according to WHO targets. Ceramic filters showed intermediate retail prices and high prices per $\mathrm{m}^{3}$ with a range of removal efficiencies for bacteria from "non-protective" to "highly protective" and for viruses "non-protective". Biosand filters had high retail prices and low prices per $\mathrm{m}^{3}$ with a range of removal efficiencies for bacteria from "non-protective" to "protective" and for viruses from "non-protective" to "highly protective". The reported log removal should be viewed with some precaution, as parameters like indicator pathogen, research method and human factors are of influence. Also, most studies are short-time (around 26 weeks) and designed poorly unblinded, which could have given biased results (Hunter, 2009; Sobsey et al., 2008). The costs of HWTS were based on four parameters: production, distribution, taxes and marginal fees. They influence the price paid by the consumer besides other factors (interest, inflation). Additionally, the produced volume of water, or lifetime of the HWTS determines the actual price per $\mathrm{m}^{3}$.

Acknowledgements. The authors would like to thank Jens Groot (Basic Water Needs), Herman Jansen (PRACTICA Foundation), Sreymeh Chan (RDI), Kaira Wagoner (Potters for Peace) and Laura Schuelert (CAWST) for their contribution to this research.

Edited by: Luuk Rietveld

\section{References}

Acra, A., Jurdi, M., Mu'allem, H., Karahagopian, Y., and Raffoul, Z.: Water disinfection by solar radiation: assessment and application, International Development Research Centre, 1990.

Ahammed, M. M. and Davra, K.: Performance evaluation of biosand filter modified with iron oxide-coated sand for household treatment of drinking water, Desalination, 276, 287-293, 2001.

Akvopediam: UV treatment/ Solar disinfection. Retrieved 26th November, 2014, available at: http://akvopedia.org/wiki/Sodis (last access: 5 April 2016), 2013.

Akvopedia: Ceramic Candle filter, available at: http://akvopedia. org/wiki/Ceramic_candle_filter, last access: 26 November 2014a.

Akvopedia: Ceramic pot filter, available at: http://akvopedia.org/ wiki/Ceramic_pot_filter, last access: 7 March 2014b.

Akvopedia: Concrete Biosand Filter, available at: http://www. akvopedia.org/wiki/Concrete_Biosand_Filter, last access: 21 July 2014c.

Basic Water Needs: Tulip Waterfilters, available at: www. basicwaterneeds.com/, last access: 1 December 2014.

Baumgartner, J., Murcott, S., and Ezzati, M.: Reconsidering "appropriate technology": the effects of operating conditions on the bacterial removal performance of two household drinking-water filter systems, Environ. Res. Lett., 2, 024003, 2007.

Bielefeldt, A. R., Kowalski, K., Schilling, C., Schreier, S., Kohler, A., and Scott Summers, R.: Removal of virus to protozoan sized particles in point-of-use ceramic water filters, Water Res., 44, 1482-1488, 2010.

Bloem, S. C., van Halem, D., Sampson, M. L., Huoy, L.-S., and Heijman, B.: Silver impregnated ceramic pot filter: flow rate versus the removal efficiency of pathogens, Disinfection, 2009.

Bloomberg: Markets, available at: http://www.bloomberg.com/ markets/, last access: 6 December 2014.

Brown, Proum, S., and Sobsey, M.: Sustained use of a householdscale water filtration device in rural Cambodia, J. Water Health, 7, 404-412, 2009.

Brown Sobsey, M. D. and Loomis, D.: Local drinking water filters reduce diarrheal disease in Cambodia: a randomized, controlled trial of the ceramic water purifier, Am. J. Trop. Med. Hyg., 79, 394-400, 2008.

Brown, J.: Effectiveness of ceramic filtration for drinking water treatment in Cambodia, ProQuest, 2007.

Brown, J. and Sobsey, M.: Microbiological effectiveness of locally produced ceramic filters for drinking water treatment in Cambodia, Journal Water Health, 8, 1-10, 2010.

CAWST: Household Water Treatment and Safe Storage Fact Sheet, available at: www.resources.cawst.org/package/ household-water-treatment-and-safe-storage-fact-sheets-detailed_ en (last access: 1 December 2014), 2012.

Chilvers, K., Reed, R., and Perry, J.: Phototoxicity of Rose Bengal in mycological media-implications for laboratory practice, Lett. Appl. Microbiol., 28, 103-107, 1999.

Dejung, S., Fuentes, I., Almanza, G., Jarro, R., Navarro, L., Arias, G., and Iriarte, M.: Effect of solar water disinfection (SODIS) on model microorganisms under improved and field SODIS conditions, J. Water Supply Res. T., 56, 245-256, 2007.

Duffy, E., Al Touati, F., Kehoe, S., McLoughlin, O., Gill, L., Gernjak, W., and Cassidy, J.: A novel $\mathrm{TiO}_{2}$-assisted solar photocatalytic batch-process disinfection reactor for the treatment of biological and chemical contaminants in domestic drinking water in developing countries, Solar Energ., 77, 649-655, 2004.

Duke, W., Nordin, R., Baker, D., and Mazumder, A.: The use and performance of BioSand filters in the Artibonite Valley of Haiti: a field study of 107 households, Rural Remote Health, 6, 570, 2006.

Elliott, M., DiGiano, F., and Sobsey, M.: Virus attenuation by microbial mechanisms during the idle time of a household slow sand filter, Water Res., 45, 4092-4102, 2011.

Elliott, M., Stauber, C., Koksal, F., DiGiano, F., and Sobsey, M.: Reductions of E. coliechovirus type 12 and bacteriophages in an intermittently operated household-scale slow sand filter, Water Res., 42, 2662-2670, 2008.

Fujioka, R. and Yoneyama, B.: Sunlight inactivation of human enteric viruses and fecal bacteria, Water Sci. Technol., 46, 291-295, 2002.

Heaselgrave, W., Patel, N., Kilvington, S., Kehoe, S. C., and McGuigan, K. G.: Solar disinfection of poliovirus and Acanthamoeba polyphaga cysts in water - a laboratory study using simulated sunlight, Lett. Appl. Microbiol., 43, 125-130, doi:10.1111/j.1472-765X.2006.01940.x, 2006.

Heinsbroek, A. and Peters, T.:Solar Water DIsinfection in Developing Countries, CIE5421 Water \& Health Technology Review Essay, 2014.

Huisman, L., Wood, W., and Organization, W. H.: Slow sand filtration, World Health Organization Geneva, Vol. 16, 1974. 
Hunter, P. R.: Household water treatment in developing countries: comparing different intervention types using meta-regression, Environ. Sci. Technol., 43, 8991-8997, 2009.

Hwang, H. G., Kim, M. S., Shin, S. M., and Hwang, C. W.: Risk Assessment of the Schmutzdecke of Biosand Filters: Identification of an Opportunistic Pathogen in Schmutzdecke Developed by an Unsafe Water Source, Int. J. Environ. Res. public health, 11, 2033-2048, 2014.

Joyce, T., McGuigan, K., Elmore-Meegan, M., and Conroy, R.: Inactivation of fecal bacteria in drinking water by solar heating, Appl. Environ. Microbiol., 62, 399-402, 1996.

Lantagne, D.: Investigation of the Potters for Peace colloidal silver impregnated ceramic filter: Report 1: Intrinsic effectiveness, lethia Environmental, Boston, MA:, USA, 2001.

Lonnen, J. K. S., Kehoe, S. C., Al-Touati, F., and McGuigan, K. G.: Solar and photocatalytic disinfection of protozoan, fungal and bacterial microbes in drinking water, Water Resour. Res., 39, 877-883, 2005.

Martín-Domínguez, A., Alarcón-Herrera, M. T., MartínDomínguez, I. R., and González-Herrera, A.: Efficiency in the disinfection of water for human consumption in rural communities using solar radiation, Solar Energ., 78, 31-40, doi:10.1016/j.solener.2004.07.005, 2005.

McGuigan, K. G., Conroy, R. M., Mosler, H.-J., Preez, M. d., Ubomba-Jaswa, E., and Fernandez-Ibañez, P.: Solar water disinfection (SODIS): A review from bench-top to roof-top, J. Hazard. Materials, 235, 29-46, 2012.

Meierhofer, R. and Landolt, G.: Factors supporting the sustained use of solar water disinfection - Experiences from a global promotion and dissemination programme, Desalination, 248, 144151, 2009.

Meierhofer, R.: Establishing solar water disinfection as a water treatment method at household level, Madagascar Conservation \& Development, 1, 25-30, 2006.

Meyer, V. and Reed, R.: SOLAIR disinfection of coliform bacteria in hand-drawn drinking water, Water SA, 27, 49-52, 2004.

Murphy, H., McBean, E., and Farahbakhsh, K.: A critical evaluation of two point-of-use water treatment technologies: can they provide water that meets WHO drinking water guidelines?, J. Water Health, 8, 611-630, 2010a.

Murphy, H., McBean, E., and Farahbakhsh, K.: Nitrification, denitrification and ammonification in point-of-use biosand filters in rural Cambodia, J. Water Health, 8, 803-817, 2010b.

NWP: Netherlands Water Partnership Smart Disinfection Solutions Smart Solutions, 2010.

Oyanedel-Craver, V. A. and Smith, J. A.: Sustainable colloidalsilver-impregnated ceramic filter for point-of-use water treatment, Environ. Sci. Technol., 42, 927-933, 2007.

Palmateer, G.: Toxicant and parasite challenge of Manz intermittent slow sand filter, Environ. Toxicol., 14, 217-225, 1999.

Potters for Peace: Ceramic Water Filter Project, available at: http: //pottersforpeace.com/?page_id=8 (last access: 5 April 2016), 2014.

Rayner, J., Skinner, B., and Lantagne, D.: Current practices in manufacturing locally-made ceramic pot filters for water treatment in developing countries, Journal of Water, Sanitation and Hygiene for Development, 3, 252-261, 2013.
Reed, R. H.: The inactivation of microbes by sunlight: solar disinfection as a water treatment process, Adv. Appl. Microbiol., 54, 333-366, 2004.

Ren, D. and Smith, J. A.: Retention and transport of silver nanoparticles in a ceramic porous medium used for point-of-use water treatment, Environ. Sci. Technol., 47, 3825-3832, 2013.

Roberts, M.: Ceramic Water Purifier Cambodia Field Tests, Phnom Penh: International Development Enterprises Working Paper, 2013.

Russell, A. D. and Hugo, W. B.: 7 Antimicrobial Activity and Action of, Progress in Medicinal Chemistry, 31, 351-366, 1994.

Simonis, J. J. and Basson, A. K.: Evaluation of a low-cost ceramic micro-porous filter for elimination of common disease microorganisms, Phys. Chem. Earth, 36, 1129-1134, 2011.

Sobsey, M. D., Stauber, C. E., Casanova, L. M., Brown, J. M., and Elliott, M. A.: Point of use household drinking water filtration: a practical, effective solution for providing sustained access to safe drinking water in the developing world, Environ. Sci. Technol., 42, 4261-4267, 2008.

Sodis.ch.: Microbiology, available at: http://www.sodis.ch/ methode/forschung/mikrobio/index_EN (last access: 1 March 2015), 2011.

Sswm.info.: Biosand Filter, available at: www.sswm.info/ category/implementation-tools/water-purification/hardware/ point-use-water-treatment/bio-sand-filtrat, last access: 1 December 2014.

Stauber, C. E., Ortiz, G. M., Loomis, D. P., and Sobsey, M. D.: A randomized controlled trial of the concrete biosand filter and its impact on diarrheal disease in Bonao, Dominican Republic, Am. J. Trop. Med. Hyg., 80, 286-293, 2009.

Stuurman, D. J., Tielemans, M. W. M., and Nederstigt, J. M. J.: Marketing first: Getting ceramic pot filters to the target group, edited by: Initiative of Aqua for All research group of Cermaic Pot Filters, 1-22, available at: http://practica.org/wp-content/uploads/2014/08/ Marketing-first-Getting-Ceramic-Pot-Filters-to-the-Target-Group. pdf (last access: 5 April 2016), 2010.

Tulipfilter: Product Details, Wat je weten wilt over een Tulip water filter, available at: http://www.tulipwaterfilter.nl/?s_page_id=575 (last access: 26 November 2014), 2013.

Unicef and WHO: World Health Organization: Progress on drinking water and sanitation: update, Nueva York: UNICEF, available at: http://apps.who.int/iris/bitstream/10665/81245/1/ 9789241505390_eng.pdf (last access: 5 April 2016), 2012.

van der Laan, H., van Halem, D., Smeets, P., Soppe, A., Kroesbergen, J., Wubbels, G., and Heijman, S.: Bacteria and virus removal effectiveness of ceramic pot filters with different silver applications in a long term experiment, Water Res., 51, 47-54, 2014.

Van Halem, D., Heijman, S., Soppe, A., van Dijk, J., and Amy, G.: Ceramic silver-impregnated pot filters for household drinking water treatment in developing countries: material characterization and performance study, Water Sci. Technol., 7, 9-17, 2007.

Vanderzwaag, J. C., Atwater, J. W., Bartlett, K. H., and Baker, D.: Field evaluation of long-term performance and use of biosand filters in Posoltega, Nicaragua, Water Quality Research Journal of Canada, 44, 111-121, 2009.

Wang, H., Narihiro, T., Straub, A. P., Pugh, C. R., Tamaki, H., Moor, J. F., and Nguyen, T. H.: MS2 Bacteriophage Reduction and Mi- 
crobial Communities in Biosand Filters, Environ. Sci. Technol., 48, 6702-6709, 2014.

Weber-Shirk, M. L. and Dick, R. I.: Physical-chemical mechanisms in slow sand filters, Journal-American Water Works Association, 89, 87-100, 1997.

Wegelin, M., Canonica, S., Alder, A., Marazuela, D., Suter, M., Bucheli, T. D., and Kelly, M.: Does sunlight change the material and content of polyethylene terephthalate (PET) bottles?, AquaJournal of Water Supply, 50, 125-134, 2001.

Wegelin, M., Canonica, S., Mechsner, K., Fleischmann, T., Pesaro, F., and Metzler, A.: Solar water disinfection: scope of the process and analysis of radiation experiments, Aqua, 43, 154-169, 1994.
Wegelin, M. and De Stoop, C.: Potable water for all: promotion of solar water disinfection, Paper presented at the WEDC Conference, 1999.

Wegelin, M. and Sommer, B.: Solar Water Disinfection (SODIS) destined for worldwide use?, Waterlines, 16, 30-32, 1998.

WHO: Database on Water, Sanitation and Hygiene, Database WHO, availablte at: http://www.who.int/water_sanitation_ health/publications/2011/evaluating_water_treatment.pdf (last access: 5 April 2016), 2004.

Young-Rojanschi, C. and Madramootoo, C: Intermittent versus continuous operation of biosand filters, Water Res., 49, 1-10, 2014. 